\title{
Sustainable use of Savanna Vegetation in West Africa in the Context of Climate and Land use Change
}

\author{
Karen Hahn and Anna Leßmeister
}

\begin{abstract}
West African savannas undergo severe changes due to climate change and land use pressure, resulting in degradation and biodiversity loss. These changes directly impact local rural livelihoods, as many cash poor rural communities depend on the provisioning ecosystem services of their environments. In a case study of the interdisciplinary research project UNDESERT, the increasingly challenging sustainable use of wild plant species in West African savannas was investigated. In this study, we present the results and give examples of how scientific results can serve for practical actions to foster sustainable use of important plant resources.
\end{abstract}

\section{Introduction}

Savannas are one of the most important ecosystems in Africa. They cover more than half of the continent and provide important ecosystem services for the livelihoods of millions of people. Also for global dynamics, they are relevant as they deliver approximately $30 \%$ of terrestrial net primary production and store about

K. Hahn ( $₫)$

Institut für Ökologie, Evolution und Diversität der Goethe-Universität in Frankfurt am Main, Frankfurt am Main, Deutschland

E-Mail: karen.hahn@bio.uni-frankfurt.de

A. Leßmeister

Technische Universität Darmstadt, Darmstadt, Deutschland

E-Mail: anna.lessmeister@tu-darmstadt.de 
$15 \%$ of the carbon on Earth (Grace et al. 2006). Savannas are generally characterized by a continuous grass layer combined with a spatially and temporally variable amount of trees and shrubs (Sankaran et al. 2005). Their distribution and structure is shaped particularly by the amount and seasonality of rainfall (Parr et al. 2014). In West Africa, savannas cover a wide climatic gradient with a precipitation range from $250 \mathrm{~mm} /$ year up to over $1300 \mathrm{~mm} / \mathrm{year}$, stretching from dry Sahelian savannas down to humid savannas in the south adjacent to rain forests. However, large parts of this savanna zone are old cultural landscapes as they are inhabited by humans for millennia (Breunig und Neumann 2002). Consequently, their vegetation and biodiversity is profoundly shaped by human impact in form of subsistence agriculture, livestock farming and use of wild plant species for livelihoods.

Many cash poor rural communities in West Africa depend on the provisioning ecosystem services of their environments, that is products directly obtained from the ecosystems i.e. food, and medicine (Capistrano et al. 2005). Particularly nontimber forest products (NTFPs), which comprise any products other than timber (e.g. fruits, leaves, bark, roots) derived from forests, woodlands and savannas, contribute to maintain livelihoods (Lykke et al. 2004; Paré et al. 2010; Heubach et al. 2011; Leßmeister 2018). A wide range of non-timber forest species provide plant parts which are used for food, medicine, construction materials, cosmetics, handcraft, fuels, fodder etc. Moreover, some species also provide regular cash income (Heubach et al. 2011; Leßmeister et al. 2018), as their products are sold on markets and are even exported to other countries (e.g. nuts of the shea butter tree, Vitellaria paradoxa). Changes in their availability thus, impact directly on the sustainability of livelihoods of rural communities in West African savannas.

In the last decennia, West African savannas underwent severe changes due to climatic changes and increasing land use pressure. Land use changes increased due to human population growth resulting in a higher demand of cultivated land for subsistence farming (Gaisberger et al. 2017). Additionally, the promotion of cash crop cultivation (e.g. cotton, sesame, cashew nuts) for generating cash income in addition to subsistence agriculture leads to land use intensification with increasing land allocation, use of fertilizers and pesticides. Consequently, in the diminishing remaining savanna areas, pasture pressure increased. These various land use pressures in combination with climatic changes result in increasing degradation of soil and vegetation, comprising biodiversity loss, with considerable consequences for the ecosystem services of savannas - a trend which will most probably even aggravate in the future. According to climate predictions of the latest IPCC-report (2014), West Africa will face a strong temperature increase of between $3-6{ }^{\circ} \mathrm{C}$ until 2100 , as well as severe changes in precipitation, 
combined with a higher variability of the rainfall events. Although the ranges and magnitudes of the shifts are still in debate and show high insecurities, particularly the Sahel and tropical West Africa is considered as a hot spot of changes (IPCC 2014).

Therefore, understanding the complex interactions of climatic variations and other environmental factors in concurrence with various human actions is still a key challenge (Mertz et al. 2010; Gaisberger et al. 2017). In the Sahelian zone, for example, vegetation development during the last decades is still controversially discussed (Ouedraogo et al. 2014). Remote sensing studies have documented a greening trend since the early $1980 \mathrm{~s}$, which is in parallel to an increase in rainfall since the severe droughts in the $70 \mathrm{~s}$ and $80 \mathrm{~s}$ (Herrmann and Tappan 2013; Brandt et al. 2014; Hänke et al. 2016). Contrary, field based studies observed an impoverishment of woody vegetation cover (Brandt et al. 2014), a reduction of woody species richness and a shift towards more arid-tolerant species despite these greening trends (Herrmann and Tappan 2013). Hence, multidisciplinary approaches on different, local to regional scales are required to improve the understanding of these contradictory findings.

Apart from a better understanding of savanna ecosystem changes and their drivers, strategies and actions need to be developed for more sustainable use and restoration of already degraded savanna ecosystems. Even though, various technical approaches exist, e.g. stone lines or deep ploughing for soil restoration in degraded areas, direct implementation by rural communities is still a big challenge (Vohland and Berry 2009). Therefore, involvement of stakeholders right from the start, when developing such approaches, would help to improve the acceptance and long-term sustainability (Liehr et al. 2017). Thus, transdisciplinary research approaches are required which comprise collaboration between multiple scientific disciplines and the integration of extra-scientific knowledge of practitioners and stakeholders throughout the entire research process (Jahn et al. 2012). By a transdisciplinary approach, new knowledge is created, relevant and transferable for science and societal practices (Hummel et al. 2017).

Against this background, the EU-funded transdisciplinary research project UNDESERT (Understanding and combating desertification to mitigate its impact on ecosystem services) focused on i) an improved understanding of land and vegetation degradation and its drivers, ii) the impact of these changes on ecosystem services and the consequences for rural communities, and iii) the development of practical approaches in joint action with local stakeholders for more sustainable use of vegetation in the West African savanna zone (https://undesert.neri.dk/index. php?page=Home). Scientists from different natural and social science disciplines from several European and West African Universities and research institutions as 
well as stakeholders from various levels (village dwellers up to the ministry level) were involved during the entire project phase of five years. The project aimed at scientific analysis as well as concrete practical actions to create new knowledge and practical experiences relevant for policy and decision making in regard to sustainable management of natural resources. Further important project components were dissemination activities on local to national and international scale as well as capacity development to enhance future sustainable resource managing in the frame of future demographic and climatic changes.

Within the UNDESERT-project, scientists from Goethe-University focused particularly on the provisioning ecosystem services of savannas. The increasingly challenging sustainable use of wild plant species was addressed in a case study in two villages of the savanna zone in southeast Burkina Faso (in parts published in Leßmeister et al. 2015, 2018; Leßmeister 2017). In the following, we give insights into the research approach and results from this case study in regard to its contribution to more sustainable use of wild plant species in West African savannas. Furthermore, we present examples of the UNDESERT project, of how the results can be applied and can serve for concrete practical actions to mitigate degradation and to foster sustainable use of important plant resources. Finally, we give an overview on the UNDESERT project's dissemination and capacity development activities in respect to their contribution to sustainable use of savanna vegetation.

\section{Case Study on Useful Wild Plant Species in Southeast Burkina Faso}

To gain more insights into the use of wild plant species an enhanced knowledge in regard to their socio-economic valuation as well as the species population development trends is indispensable. For a large number of West African plant species general information about their usefulness is available (Burkill 1985; Arbonnier 2000; Zizka et al. 2015). However, some recent studies showed that preferences and use values of species can differ considerably due to social and spatial differentiations, for example gender, ethnic affiliations, villages (Kepe 2008; De Caluwé et al. 2009; Heubach et al. 2011; Schumann et al. 2012). Thus, in the case study, we aimed to assess detailed data on socio-economic values of species according to different ethnic groups, gender and savanna areas to obtain more insights into the range of the valuation differences. These data are highly important for the development of appropriate conservation strategies and sound practical actions towards sustainable use of the species, as sustainable care for e.g. planted species 
by the concerned rural people is more likely when the choice of species entirely matches their interests.

To evaluate the consequences of changing species availabilities for rural communities, it is also important to estimate their economic contribution to local household income. Such economic studies improve the understanding of the contribution of NTFP-extraction to rural household economies and enable to identify protection needs of species for conservation as well as improvement of rural livelihoods (Lykke et al. 2004; Schumann et al. 2012; Heubach et al. 2011, 2013; Ouedraogo et al. 2014). Moreover, these studies provide important data for raising awareness of policy and decision makers, as the value of NTFPs is up to now hardly considered in any kind of land use planning, due to a lack of data about their economic values (Schaafsma et al. 2014; Shackleton und Pandey 2014).

\subsection{Research Approach}

To obtain more information on the socio-economic valuation of useful wild plant species, a participatory research approach was applied, were local people with their knowledge about their environment and their specific interests play a crucial role in the research process (Cunningham 2001). Two different types of interviews were applied:

A. Structured interviews with village dwellers were carried out to assess i) the use and valuation of wild plant species comprising a ranking of useful species and ii) changes in the availability of most useful species according to the local perception. For the interviews, 60 woody species were preselected on the basis of expert knowledge of the study areas and literature. Besides general information on the interviewed person, the questionnaires comprised a simple categorization into three to four categories per topic (use preferences: $0=$ not useful, $1=\mathrm{a}$ bit useful, $2=$ useful, $3=$ very useful; changes of species: $0=$ no decline, 1 $=$ a bit declining, $2=$ strong decline). Informants were randomly chosen from the two villages irrespective of age, education level and profession but by means of their ethnic affiliation and gender. The main ethnic groups of the villages, representing autochthonous farmers (Gourmantché), migrated farmers (Mossi) and migrated herders (Fulani), were considered to analyze if different use preferences occur. In each village, 24 informants (12 female, 12 male) per ethnic group were considered.

B. Structured household surveys (155 interviews) were applied in the two villages with the same rural dwellers of different ethnic groups as above, to investigate the economic contribution of non-timber forest products (NTFPs) to rural 
household revenues (for details see Leßmeister et al. 2018) and to obtain detailed information on the different use categories per species. By this, we gained further insights into the possible economic consequences of species changes for rural dwellers and how species declines might affect different use categories, for example if they can lead to specific shortages in food products. Due to determined gender roles in traditional West African rural societies, the interview was split into two parts: Women gave information about harvesting of wild foods, fire wood consumption, medical use of plants as well as for decoration and cosmetic purposes. Men gave information about the households composition and assets, sources of income as well as agricultural production including animal husbandry. All informants were asked to recall quantities harvested from cropping or gathered in the savanna woodland, and the respective amounts which were consumed, sold or bartered. Based on this information, the economic value of all NTFP providing species was calculated as well as the share of their economic value in total household income (for detailed information see Leßmeister et al. 2018). Moreover, for certain use categories (e.g. food consumption) the economically most important species were identified (Leßmeister et al. 2015).

\subsection{Use Preferences}

The results show that use preferences for the highest ranked species were very similar between people of different ethnic groups in both villages (Fig. 1). The five highest ranked species were highly important for all ethnic groups (see Fig. 1, species to the left side). All five species provide highly valued plant parts for nutrition purposes. The fruits of Vitellaria paradoxa, the shea butter tree, are consumed raw and the seeds provide the most important plant fat used for daily nutrition, health care and cosmetics (Pouliot 2012; Heubach et al. 2013). The fruits and leaves of the baobab-tree, Adansonia digitata, are also highly appreciated for alimentation: leaves serve as vegetable in daily sauces, the seeds are consumed raw or roasted, 'fruit powder' is prepared as beverage (Schumann et al. 2012). Equally the locust bean tree (Parkia biglobosa) provides fruits, which are used in manifold ways: the sweet 'fruit powder' is consumed raw, the seeds are transformed into a local spice, which has a high nutrition value and is part of daily consumed sauces (Kronborg et al. 2014). Moreover, the tamarind tree (Tamarindus indica) and the red kapok tree (Bombax costatum) possess fruits and flowers which are valued and consumed as food (Thiombiano et al. 2012). Besides, all five species are also used for a variety of other use purposes (e.g. construction, traditional medicine). 


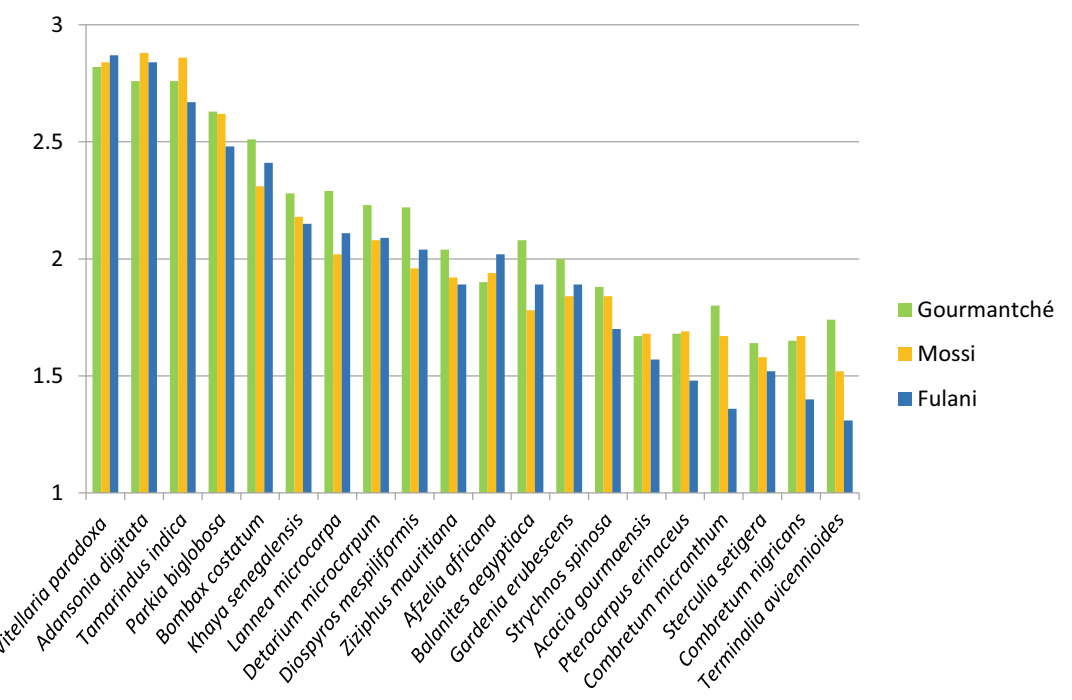

Fig. 1 Ranking of use value of species according to the three ethnic groups (scale: $1=$ a bit useful, 3 = very useful, mean for each ethnic group of the two villages)

For species overall ranked on position 6 to 20, the ranking between ethnic groups showed for some species more pronounced differences. However, for species ranked on positions above 20 , variations between the ethnic groups were even more distinct, and when considering the ranking of all 60 species, use value estimates were significantly different among ethnic groups (Gourmantché/Mossi $\mathrm{F}=$ $14,653, \mathrm{p}=0,023$, Gourmantché/Fulani $\mathrm{F}=77,594, \mathrm{p}=0,002$, Mossi/Fulani $\mathrm{F}$ $=41,582, \mathrm{p}=0,005)$.

In regard to preferences of men and women, it showed that use value estimates were also significantly different between gender $(F=36,709, p=0,000)$. However, for the most important species, women and men ranked almost the same species, whereas for species of lower ranking positions, differences were more pronounced. This might be due to different preferences for use purposes, as in general men value fire wood and construction material providing species higher, whereas women prefer species providing food and health care products. Related to the locality (two different villages), the use value estimates were also significantly different $(F=10,759, p=0,000)$. For species with high ranking value, differences between the two villages were less pronounced, whereas species of lower ranking position showed more variation in their ranking values between the villages. 
Overall, the results showed that significant differences in preferences among ethnic groups, gender and different villages occurred although the highest ranked species generally were common in all categories.

\subsection{Economic Contribution of Useful Plant Species to Rural Household Revenues}

To obtain more insights into the possible economic consequences related to changes in useful species availabilities, we analyzed the general economic contribution of useful plants to household income (Leßmeister et al. 2018). Overall the results for all interviews together revealed a high economic importance of NTFPs in the rural households economy of the village dwellers. With an average income share of $45 \%$, income from NTFPs accounted for the second largest share in total household income, next to income from crop production (49\%), off farm income (5\%) and livestock (1\%) (Fig. 2). Thus, the sufficient availability of NTFP providing species is highly important for the livelihoods of these rural communities.

In regard to the different use categories of the non-timber forest products, fodder species were economically most important, as they contributed with $61 \%$ to the total share of NTFP-income. With a contribution of 30\% to NTFP-income, firewood was the second most important use category. Plant parts for food consumption contributed with $6 \%$ and tooth twigs with $4 \%$ to total NTFP-income

Fig. 2 Household income of all 155 interviewed households together, per income group in percent (adapted after Leßmeister et al. 2018)

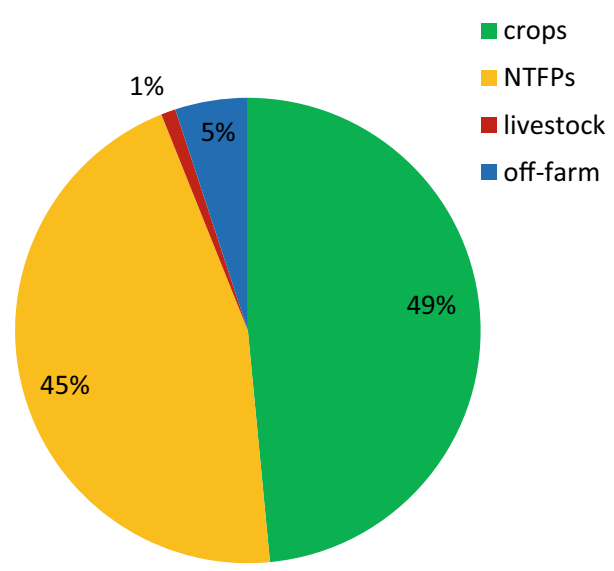


(Leßmeister et al. 2018). In the food category, four economically most important species were identified: highest income share was provided by the shea tree (Vitellaria paradoxa, $43 \%$ of wild food income), the locust bean tree (Parkiabiglobosa, 26\% of wild food income), the red kapok tree (Bombax costatum, 9\% of wild food income) and the baobab (Adansonia digitata, $7 \%$ of wild food income), (Leßmeister et al. 2015).

Comparing the three ethnic groups, we discovered significant differences in NTFP dependency due to different traditional uses and harvesting practices (Fig. 3). The pastoralist society (Fulani) showed the highest income share from NTFPs among ethnic groups (62\%), which is partly due to their higher demand of fodder species for their cattle. Differences in income share between the two farmer societies (Gourmantche, Mossi) were less pronounced. However, we discovered also significant differences in the economic contribution of NTFPs to household incomes between the two investigated villages, presumably reflecting differences in the availability of certain species in their surroundings (Leßmeister et al. 2018).

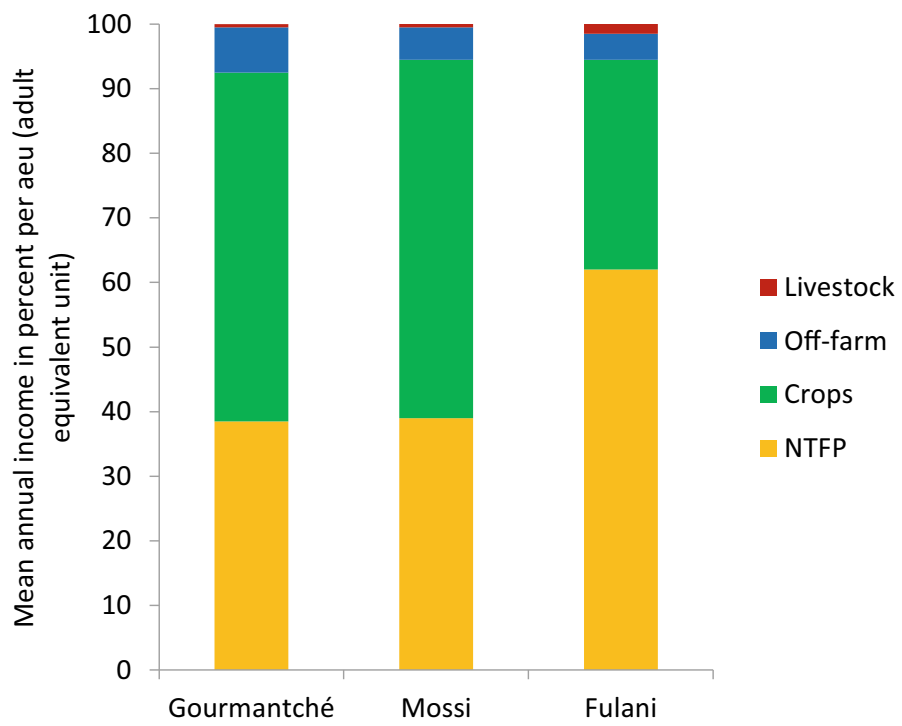

Fig.3 Mean annual income share per aeu (adult equivalent unit) in percent for each income group for the three ethnic groups (Gourmantché, Mossi, Fulani) (adapted after Leßmeister et al. 2018) 
Overall, these results showed that NTFPs provide considerable and significant cash and non-cash income to local livelihoods, and the need of detailed systematic collection of income data from NTFP species on a local scale. Consequently, management recommendations for more sustainable use of NTFP species need to consider ethnic-specific NTFP use patterns and habits as well as local differences with regard to site-specific species compositions. This knowledge is essential to inform national poverty assessments and national accounting, forming the basis of strategic planning and policy making (Leßmeister et al. 2018).

\subsection{Perception of Species Changes and Possible Consequences for Users}

The perception and knowledge of local resource users provide valuable insights into the local vegetation and its development (Cunningham 2001; Paré et al. 2010). It is one of the most important sources for indications on species population changes as in general abundance data on the former population status lack for West African countries (Wezel und Lykke 2006).

The results show that in both villages many useful species were perceived as declining by the rural dwellers. Fig. 4 gives an overview on the perception of decline for the most important species according to the ranking of the species (overall use value for all ethnic groups). It shows that among the 10 highest ranked useful species, six were perceived as strongly declining, the others as declining. Thus, we can presume pronounced socio-economic consequences for the rural communities as the highest ranked species are all perceived as severely to moderately declining in the study areas.

To gain further insights into the possible consequences for rural dwellers, we analyzed how these species declines might affect different use categories. It revealed that the most important food providing species were all perceived as either 'strongly declining' (e.g. Adansonia digitata, Tamarindus indica, Bombax costatum) or 'declining' (e.g. Vitellaria paradoxa, Parkia bioglobsa). The decreasing availability of food-providing species will most probably lead to shortages of important food products and supposes considerable consequences for rural household incomes in the future (Leßmeister et al. 2015). In regard to medical care, some highly valued species were also perceived as strongly declining (e.g. Khaya senegalensis), others as moderately decreasing. Overall, this might have pronounced effects for health care as the alternative use of less preferred species in case of shortages can play a role for the quality of the medication. In regard to species used for construction and tools (e.g. Anogeissus leiocarpus, Balanites 


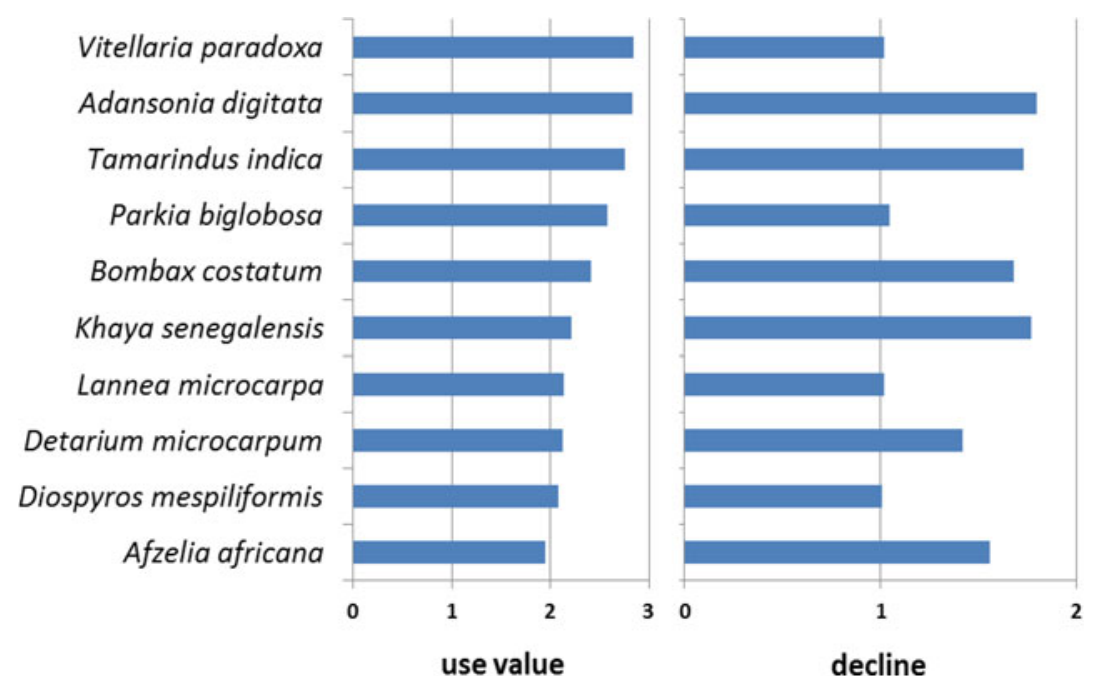

Fig. 4 Overall use values and perception of change (scale use value: $0=$ not useful, $3=$ very useful; scale change: $0=$ no decline, $2=$ strong decline)

aegyptiaca) (Schumann et al. 2011; Okia et al. 2011), less severe consequences can be expected as these species were perceived mostly as moderately declining and, in addition, other species can be used for these purposes. The same counts for the use of fire wood as energy supply: the most valued species were estimated as moderately declining and other species can be optionally used (e.g. Combretum nigricans instead of Vitellaria paradoxa). Contrary, for fodder availability, relevant consequences can be expected, as some highly valued fodder species (Khaya senegalensis) (Houehanou et al. 2011) were perceived as strongly declining. Particularly in the dry season, when branches and leaves of woody species are chopped for the cattle, problems for fodder provision can occur, as there are only few alternative tree and shrub species.

Overall, the case study revealed a very high valuation and reliance of village dwellers on non-timber forest product providing species. As most woody species are multi-purpose species, as their plant parts serve for several use categories, a diminishing availability of these species will have consequences for divers use categories. In some cases, a decreasing availability of one species might be substituted by the use of alternative species. However, as most of the highly useful 
species are perceived as severely declining, an alternative use is no option to meet the demands in the long run (Leßmeister et al. 2015).

Furthermore, the results show that significant differences in preferences among ethnic groups, gender and different villages occurred although the highest ranked species generally were common in all categories. However, already a slight difference in preferences is important in cases where only a reduced number of species can be considered for e.g. planting measures or other measures to foster their sustainable use. Particularly, planting measures with either women groups or men groups should consequently consider different preferences. Thus, the results underline the necessity to obtain detailed knowledge on user's preferences in each case of practical actions.

\section{Practical Actions for Sustainable Use and Conservation}

To deal with species decline and the consequences for rural livelihoods, planting approaches are valuable measures. Moreover, they can be combined with payments for carbon certification to generate additional income (Lykke et al. 2016). Thorough selection of tree species in tree plantings, considering local communities' preferences and the economic income options from NTFP-providing species can also significantly increase the value of carbon certification projects. However, tree planting of native species is not a tradition in West African societies, despite the fact that rural dwellers are well aware and concerned about the decline of various useful species. Rural communities lack knowledge and experience in planting native trees, although when asked about planting interests, preferences for native species are clearly expressed (Lykke et al. 2016).

Thus, in addition to the knowledge about socio-economic use values, assessments of planting interests of local communities are required as an important source of information for tree species selection in relation to management and conservation projects. In the frame of the UNDESERT project, an assessment of planting interests of local communities was carried out in one study area in Senegal, where a carbon certification project was implemented (https://www.planvivo. org/docs/Arlomom-PDD_published.pdf). To consider local dwellers preferences and needs, 120 people of 10 villages in this project area were asked to provide a ranking value for 55 local tree species of the study area regarding their planting interest.

It showed that all 55 woody species were considered of planting interest, with low variation of the highest ranked species between the villages. Overall, women had a significantly higher interest in tree planting for $22 \%$ of the species than 
men. However, the most useful species were generally common among all groups. Planting of fruit species was prioritized. Thus, local knowledge ensures high focus on food security and local income. In a second step, species preferences need to be combined with practical issues such as availability of seeds, sprouting potential in nurseries and knowledge in growing the species, e.g. by forestry services (Lykke et al. 2016).

For plantings of tree species, as part of the carbon certification project, these results were used as a basis for selecting the species, with taking practical feasibility and experience for species plantings into account. Overall, the results showed that a local knowledge based thorough selection of preferred species can supply local people with products that are highly interesting in terms of local consumption as well as income generation. Thus, with the right species selection, planting projects can provide additional income and food security in the long term. In the case of carbon certification projects, the payment for ecosystem services (PES) provides an important additional income, particularly during the first challenging years. This helps considerably to maintain the plantings until the plants start to produce valued plant parts for e.g. food consumption and other use purposes.

Likewise, assessments of planting interests of rural communities can be applied to identify species of interest for restoration approaches of degraded savanna areas. In the frame of UNDESERT, this approach was applied to combine restoration experiments comprising different traditional and modern restoration techniques for soil treatment (zaï, half-moon, agricultural benches and stone lines deep ploughing) with plantings of native species to foster soil regeneration and rainwater harvesting. Species preferences of rural dwellers were cross-linked with the species' ecology to grow on degraded soils for the final choice of species. Several species of socio-economic interest have been chosen for the experimental sites of the long-term restoration experiments (Bayen et al. 2016). Based on their socio-economic values and their performance in the plantations (survival rate, growth, adaptation to water stress), a number of species were finally highly recommended for successful restoration of degraded lands according to different soil types, topography and climate conditions (Lykke et al. 2016).

Both approaches show, how practical measures can be improved and can profit from involvement of local stakeholders considering their local knowledge and preferences, and by this raise the acceptance and care of the stakeholders for the measures. 


\section{Dissemination and Capacity Development to Foster Sustainable use}

Besides concrete practical approaches, dissemination of scientific findings to the scientific community as well as to the public can contribute to sustainable use of plant resources in savannas. The creation and dissemination of new knowledge relevant and transferable for science and societal practices is a key component of any transdisciplinary approach (Jahn et al. 2012), ideally carried out by both scientists and societal actors. This step is also defined as "codissemination" in the frame of the future earth process to foster sustainability science (Mauser et al. 2013).

The UNDESERT project developed various products and tools for dissemination on different scales, ranging from simple fact sheets on practical actions such as tree plantings in restoration measures up to decision support tools addressing the local to national policy and land management planning level (Lykke et al. 2016). To provide broad access to the scientific results for the scientific community as well as the public, several online databases were created and developed by the involved scientists from the Senckenberg Research Institute and Natural History Museum Frankfurt (Schmidt et al. 2012; Dressler et al. 2014). An online data portal provides data availability and exchange between research and applied use. It is composed of three different modules:

1. The West African Data and Metadata Repository (https://westafricandata.sen ckenberg.de/) which is a data warehouse for a variety of ecological and socioeconomic data (Gerstner et al. 2015), including for example ethnobotanical data on plant use, environmental changes according to the local perception, modelled distributions of functional plant groups, indicator values for degradation, etc..

2. The West African Vegetation Database (https://westafricanvegetation.sencke nberg.de), which gives access to vegetation data useful for studies of vegetation composition and plant diversity changes, plant distribution, etc. (Schmidt et al. 2012).

3. The West African Plant Database (https://www.westafricanplants.senckenbe rg.de), which is a photo archive and an identification tool for West African plants documenting more than $30 \%$ of the West African plant species and most of its savanna species (Dressler et al. 2014). Besides the photos themselves, it is an important source of occurrence and trait data, and receives enormous positive feedback from the scientific community as well as the public. This database also very successfully integrates the source of expert 
knowledge from non-professional botanist with good field experience. It can be used and improved at any time by substantial knowledge available from societal actors, like extension workers, foresters, agriculturists, teachers and non-professional botanists.

Moreover, relevant data of these databases contribute to international science infrastructures providing free and easy access to various biodiversity data, such as the Global Biodiversity Information Facility (GBIF), Map of Life (MoL) or the Encyclopedia of life (EoL).

Thus, such online tools are widely accessible and comprise numerous highly detailed data, which are otherwise difficult to access. They are relevant tools for research, education and management. The collection of extensive botanical and environmental data enabled for instance a complete conservation assessment for the flora of Burkina Faso based on IUCN criteria (Schmidt et al. 2017). This sound and comprehensive conservation assessment is an important basis to conserve the native flora and vegetation and thus, indirectly, contributes to fight degradation and support sustainable use of vegetation and local livelihoods (Lykke et al. 2016).

A further important role plays capacity development. In the frame of the UNDESERT project, a new generation of experts in degradation issues and sustainability was educated: Fourteen young $\mathrm{PhD}$ students were trained in interdisciplinary research teams and were partly directly involved in the practical actions (e.g. restoration approaches). This capacity development component is of high importance for biodiversity conservation and approaches of sustainable use as scientists trained in such interdisciplinary environments are outstanding multipliers in their environment. They generally distribute their new interdisciplinary knowledge by teaching and training others, or by working in ministries, extension services or in development organizations. Moreover, there is an international need for young well trained scientists in the field of biodiversity conservation and ecosystem services to contribute to international science policy, working across different disciplines (Lambini und Heubach 2017). Thus, they contribute considerably to the dissemination and transfer of the new scientific knowledge into practical approaches as well as into the policy and decision making level.

\section{Conclusion}

The case study investigations on socio-economic values of wild plant species and their sustainable use demonstrated the importance of such local assessments and 
the involvement of directly concerned local stakeholders into the research process as key knowledge holders. The study showed that NTFP-species provide significant socio-economic contributions to local livelihoods and important products for divers use purposes. In regard to the range of valuation differences, high similarities for the most valued species regardless of ethnic affiliations and gender occurred, whereas for lower ranked species valuation differences were more pronounced. We conclude that, wherever feasible, practical measures should always be based on local assessments to perfectly match local needs and interests. Furthermore, we demonstrated how local knowledge and preferences can be considered in promising practical planting approaches combined with payments of ecosystem services (carbon certification) and restoration approaches to improve the interest and acceptance of the rural population in order to develop more effective sustainable management approaches.

However, local knowledge and experience about species and environmental changes should at best be completed by detailed scientific assessments of NTFP species declines and their drivers to entangle the complex effects of climate, land use change and overharvesting, in order to additionally improve mitigation strategies and actions (e.g. determination of sustainable harvesting rates). In any case, local knowledge and interests for practical measures are a first valuable step to foster sustainable use of useful savanna plant species.

Moreover, the results on the economic contribution of NTFP-species to household incomes provide important information for raising awareness and for policy and decision makers, who so far often undervalue and neglect the role of NTFPspecies in their policies. Cash crop cultivation (cotton), for instance, is promoted in national plans without considering the economic loss through diminishing useful tree species going along with cotton cultivation. This accounts even more, as food providing tree species are particularly affected.

These data on the socio-economic contribution of useful species to rural livelihoods are also important for national records as contribution to the Strategic Plan of Biodiversity 2011-2020 (so-called 'AICHI-targets') of the Convention on Biological Diversity (CBD) to improve biodiversity conservation. One of the aims of the Strategic Plan (AICHI-target 2) is to integrate biodiversity values into national and local developing and poverty reduction strategies and to incorporate economic values of biodiversity into national accountings. Furthermore, such data are highly required for the African Assessment Report on Biodiversity and Ecosystem Services of IPBES (Intergovernmental Science-Policy Platform on Biodiversity and Ecosystem Services). These reports provide credible information needed for wellinformed decision-making to reverse the current unsustainable use of many plant resources. In this regard, the UNDESERT projects' dissemination activities serve 
well to distribute the projects results and outputs into national and international decision making boards.

\section{References}

Arbonnier, M. 2000. Arbre, arbustes et lianes des zones sèches d'Afrique de l'Ouest. CIRAD, MNHN, UICN, Montpellier, Weikersheim \& Paris.

Bayen, P., A.M. Lykke, und A. Thiombiano. 2016. Impact of three restoration techniques on seedling survival and growth of three species in the Sahel of Burkina Faso (West Africa). Journal of forestry research 27 (2): 313-320.

Brandt, M., C. Romankiewicz, R. Spiekermann, und C. Samimi. 2014. Environmental change in time series - An interdisciplinary study in the Sahel of Mali and Senegal. Journal of Arid Environments 105:52-63.

Breunig, P., and K. Neumann. 2002. From hunters and gatherers to food producers: New archaeological and archaeobotanical evidence from the West African Sahel. In: Ecological Change and Food Security in Africa's Later Prehistory, Eds. F. Hassan, 123-155. New York: Kluwer Academic/Plenum Publishers.

Burkill, H.M. 1985-2000. The useful plants of West Tropical Africa. Vol 1-Vol 5. Royal Botanic Gardens, Kew.

Capistrano, D., C. Samper, C., M.J. Lee, und C. Raudsepp-Hearne. 2005. Ecosystems and human well-being: multiscale assessments: Findings of the Sub-global assessments working group of the millennium ecosystem assessment. The Millennium Ecosystem Assessment Series No. 4, 388 p. Washington, D.C.: Island Press.

Cunningham, A.B. 2001. Applied ethnobotany: people, wild plant use and conservation. WWF. London: Earthscan Publications Ldt.

De Caluwé, E., S. De Smedt, A.E. Assogbadjo, R. Samson, B. Sinsin, und P. van Damme. 2009. Ethnic differences in use value and use patterns of baobab (Adansonia digitata L.) in northern Benin. African Journal of Ecology 47 (3): 433-440.

Dressler, S., M. Schmidt, und G. Zizka. 2014. Introducing African plants - a photo guide - an interactive identification tool for continental Africa. Taxon 63:1159-1161.

Gaisberger, H., R. Kindt, J. Loo, M. Schmidt, F. Bognounou, S.S. Da, et al. 2017. Spatially explicit multi-threat assessment of food tree species in Burkina Faso: A fine-scale approach. PLoS ONE 12 (9): e0184457. https://doi.org/10.1371/journal.pone.0184457.

Gerstner, E.-M., Y. Bachmann, K. Hahn, A.M. Lykke, und M. Schmidt. 2015. The West African data and metadata repository - a long-term data archive for ecological datasets from West Africa. Flora et Vegetatio Sudano-Sambesica 18:3-10.

Grace, J., et al. 2006. Productivity and carbon fluxes of tropical savannas. Journal of Biogeography 33:387-400.

Hänke, H., L. Börjeson, K. Hylander, und E. Enfors Kautsky. 2016. Drought tolerant species dominate as rainfall and tree cover returns in the West African Sahel. Land Use Policy 59:111-120.

Herrmann, S., und G. Tappan. 2013. Vegetation impoverishment despite greening: A case study from central Senegal. Journal of Arid Environments 90: 55e66. 
Heubach, K., R. Wittig, E.A. Nuppenau, und K. Hahn. 2013. Local values, social differentiation and conservation efforts: The impact of ethnic affiliation on the valuation of NTFP species in Northern Benin, West Africa. Human Ecology 41:513-533.

Heubach, K., R. Wittig, E.A. Nuppenau, und K. Hahn. 2011. The economic importance of non-timber forest products (NTFPs) for livelihood maintenance of rural West African communities: A case study from northern Benin. Ecological Economics 70:1991-2001.

Houehanou, T.D., A.E. Assogbadjo, R.G. Kakai, M. Houinato, und B. Sinsin. 2011. Valuation of local preferred uses and traditional ecological knowledge in relation to three multipurpose tree species in Benin (West Africa). Forest Policy and Economics 13:554-562.

Hummel, D., T. Jahn, F. Keil, S. Liehr, and I. Stieß. 2017. Social ecology as critical, transdisciplinary science-Conceptualizing, analyzing, and shaping societal relations to nature. Sustainability 9:1050; doi:https://doi.org/10.3390/su9071050.

IPCC. 2014. Climate Change 2014: Impacts, adaptation, and vulnerability. Part A: Global and sectoral aspects. Contribution of working group II to the fifth assessment report of the intergovernmental panel on climate change. Hrsg. Field, C.B., V.R. Barros, D.J. Dokken, K.J. Mach, M.D. Mastrandrea, T.E. Bilir, M. Chatterjee, K.L. Ebi, Y.O. Estrada, R.C. Genova, B. Girma, E.S. Kissel, A.N. Levy, S. MacCracken, P.R. Mastrandrea, L.L. White, 1132. Cambridge: Cambridge University Press.

Jahn, T., M. Bergmann, und F. Keil. 2012. Transdisciplinarity: Between mainstreaming and marginalization. Ecological Economics 79:1-10.

Kepe, T. 2008. Beyond the numbers: Understanding the value of vegetation to rural livelihoods in Africa. Geoforum 39:958-968.

Kronborg, M., J.B. Ilboudo, I.H.N. Bassolé, A.S. Barfod, H.W. Ravn, und A.M. Lykke. 2014. Correlates of product quality of soumbala, a West African non-timber forest product. Ethnobotany Research and Applications 12:25-37.

Lambini, K.L., und K. Heubach. 2017. Young scientists welcome at IPBES. Nature 550:457.

Leßmeister, A. 2017. Vegetation changes and their consequences for the provisioning service of non-timber forest products (NTFPs) in a West African savanna. Dissertation (GU Frankfurt), 174 pages.

Leßmeister, A., K. Heubach, A.M. Lykke, A. Thiombiano, R. Wittig, und K. Hahn. 2018. The contribution of non-timber forest products (NTFPs) to rural household revenues in two villages in southeastern Burkina Faso. Agroforestry Systems 92:139-155. https://doi.org/ 10.1007/s 10457-016-0021-1.

Leßmeister, A., K. Schumann, A.M. Lykke, K. Heubach, A. Thiombiano, und K. Hahn. 2015. Substitution of the most important and declining wild food species in southeast Burkina Faso. Flora et Vegetatio Sudano-Sambesica 18:11-20.

Liehr, S., J. Röhrig, M. Mehring, and T. Kluge. 2017. How the social-ecological systems concept can guide transdisciplinary research and implementation: Addressing water challenges in Central Northern Namibia. Sustainability 9:1109. doi:https://doi.org/10.3390/ su9071109

Lykke, A.M., M.K. Kristensen, und S. Ganaba. 2004. Valuation of local use and dynamics of 56 woody species in the Sahel. Biodiversity Conservation 13:1961-1990. 
Lykke, A.M., K. Hahn, M. Schmidt, J. Axelsen, A. Thiombiano, Y. Bachmann, and W. McGhee. 2016. The UNDESERT project - from research to action for combating desertification and land degradation in West Africa. https://undesert.neri.dk/uploads/PDF/12_ UNDESERT_Appendix2_OverviewSuggestions_NEW.pdf

Mauser, W., G. Klepper, M. Rice, B.S. Schmalzbauer, H. Hackmann, R. Leemans, und H. Moore. 2013. Transdisciplinary global change research: The co-creation of knowledge for sustainability. Current Opinion in Environmental Sustainability 5 (3-4): 420-431.

Mertz, O., C. Mbow, J. Østergaard Nielsen, A. Maiga, D. Diallo, A. Reenberg, A. Diouf, B. Barbier, I. Bouzou Moussa, M. Zorom, I. Ouattara, and D. Dabi. 2010. Climate factors play a limited role for past adaptation strategies in West Africa. Ecology and Society 15 (4): 25. http://www.ecologyandsociety.org/vol15/iss4/art25/.

Okia, C.A., J.G. Agea, J.M. Kimonda, R.A.A. Abohassan, P. Okiror, J. Obua, und Z. Teklehaimanot. 2011. Uses and management of Balanites aegyptiaca in drylands of Uganda. Research Journal of Biological Sciences 6:15-24.

Ouedraogo, I., J. Runge, J. Eisenberg, J. Barron, L. Sawadogo, und S. Kaboré. 2014. The regreening of the Sahel: Natural cyclicity or human-induced change? Land 3:1075-1090. https://doi.org/10.3390/land3031075.

Paré, S., P. Savadogo, M. Tigabu, J.M. Ouadba, und P.C. Odén. 2010. Consumptive values and local perception of dry forest decline in Burkina Faso, West Africa. Environment, Development and Sustainability. 12:277-295.

Parr, C.L., C.E. Lehmann, W.J. Bond, W.A. Hoffmann, and A.N. Andersen. 2014. Tropical grassy biomes: Misunderstood, neglected, and under threat. Trends in ecology \& evolution 29 (4): 205-213.

Pouliot, M. 2012. Contribution of "Women's Gold" to West African livelihoods: The case of Shea (Vitellaria paradoxa) in Burkina Faso. Economic Botany 66:237-248.

Sankaran, M., et al. 2005. Determinants of woody cover in African savannas. Nature 438:846849.

Schaafsma, M., et al. 2014. The importance of local forest benefits: Economic valuation of nontimber forest products in the eastern Arc Mountains in Tanzania. Global Environmental Change 24:295-305.

Schmidt, M., T. Janßen, S. Dressler, K. Hahn, M. Hien, S. Konaté, A.M. Lykke, A. Mahamane, B. Sambou, B. Sinsin, A. Thiombiano, R. Wittig, und G. Zizka. 2012. The West African vegetation database. Biodiversity \& Ecology 4:105-110.

Schmidt, M., A. Zizka, S. Traoré, M. Ataholo, C. Chatelain, P. Daget, S. Dressler, K. Hahn, I. Kirchmair, J. Krohmer, E. Mbayngone, J.V. Müller, B. Nacoulma, A. Ouedraogo, O. Ouedraogo, O. Sambaré, K. Schumann, J. Wieringa, G. Zizka, und A. Thiombiano. 2017. Diversity, distribution and preliminary conservation status of the flora of Burkina Faso. Phytotaxa 304 (1): 001-215. https://doi.org/10.11646/phytotaxa.304.1.1.

Schumann, K., R. Wittig, A. Thiombiano, U. Becker, und K. Hahn. 2012. Uses, management, and population status of the baobab in eastern Burkina Faso. Agroforestry Systems 85:263278.

Schumann, K., R. Wittig, A. Thiombiano, U. Becker, und K. Hahn. 2011. Uses and management strategies of the multipurpose tree Anogeissus leiocarpa in eastern Burkina Faso. Flora et Vegetatio Sudano-Sambesica 14:10-19.

Shackleton, C.M., und A.K. Pandey. 2014. Positioning non-timber forest products on the development agenda. Forest Policy and Economics 38:1-7. 
Thiombiano, A., M. Schmidt, S. Dressler, A. Ouédraogo, K. Hahn, and G. Zizka. 2012. Catalogue des plantes vasculaires du Burkina Faso. Boissiera 65. Conservatoire et jardin botaniques de la ville de Genève. 391 S. ISBN 978-2-8277-0081-3.

Vohland, K., und B. Barry. 2009. A review of in situ rainwater harvesting (RWH) practices modifying landscape functions in African drylands. Agriculture, Ecosystems and Environment 131:119-127.

Wezel, A., und A.M. Lykke. 2006. Woody vegetation change in Sahelian West Africa: Evidence from local knowledge. Environment Development and Sustainability 8:553-567. https://doi.org/10.1007/s10668-006-9055-2.

Zizka, A., A. Thiombiano, S. Dressler, B.M.I. Nacoulma, A. Ouédraogo, I. Ouédraogo, O. Ouédraogo, G. Zizka, K. Hahn, und M. Schmidt. 2015. Traditional plant use in Burkina Faso (West Africa): A national-scale analysis with focus on traditional medicine. Journal of Ethnobiology and Ethnomedicine. 11:9. https://doi.org/10.1186/1746-4269-11-9.

Hahn, Karen, Dr., Wissenschaftliche Mitarbeiterin am Institut für Ökologie, Evolution und Diversität des Fachbereichs Biowissenschaften der Goethe-Universität Frankfurt am Main, https://www.bio.uni-frankfurt.de/53281651/Karen_Hahn

Leßmeister, Anna, Dr., Kooperationsmanagerin der Rhein-Main Universitäten an der Technischen Universität Darmstadt, https://www.intern.tu-darmstadt.de/dez_i/dezernat_i_1 eitung/Index.de.jsp

Open Access Dieses Kapitel wird unter der Creative Commons Namensnennung 4.0 International Lizenz (http://creativecommons.org/licenses/by/4.0/deed.de) veröffentlicht, welche die Nutzung, Vervielfältigung, Bearbeitung, Verbreitung und Wiedergabe in jeglichem Medium und Format erlaubt, sofern Sie den/die ursprünglichen Autor(en) und die Quelle ordnungsgemäß nennen, einen Link zur Creative Commons Lizenz beifügen und angeben, ob Änderungen vorgenommen wurden.

Die in diesem Kapitel enthaltenen Bilder und sonstiges Drittmaterial unterliegen ebenfalls der genannten Creative Commons Lizenz, sofern sich aus der Abbildungslegende nichts anderes ergibt. Sofern das betreffende Material nicht unter der genannten Creative Commons Lizenz steht und die betreffende Handlung nicht nach gesetzlichen Vorschriften erlaubt ist, ist für die oben aufgeführten Weiterverwendungen des Materials die Einwilligung des jeweiligen Rechteinhabers einzuholen.

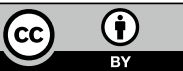

